\section{Basic Research Methods} for Librarians, by Ronald R. Powell (213 pages, 2d ed., November 1991), considers basic research methods, as opposed to applied research methods, and sets out the skills necessary for a librarian to conduct rigorous scientific research. Topics explored include developing a research study, survey research and sampling, data collection, experimental research, data analysis, and writing research proposals and reports. This second edition is a revision and reorganization of the first edition. The chapter on historical research has been expanded to include sections on library history and bibliographical research. Copies are available for $\$ 39.50$ from Ablex Publishing, 355 Chestnut Street, Norwood, NJ 07648-2090. ISBN 0-89391-688-9.

\section{The Design of Bibliographies: Observa-} tions. References and Examples, by Sidney E. Berger (224 pages, January 1992), discusses the basics of book typography and gives examples of the format of different kinds of bibliographies. Berger focuses on physical packaging as a vital part of the presentation of bibliographic data. It includes appendixes with numerous illustrations. A copy may be ordered for $\$ 85.00$ from Greenwood Press, 88 Post Road West, Box 5007, Westport, CT 06881. ISBN 0313-28425-3.

\section{The Directory of Government Document} Collections and Librarians, edited by Judy Horn (6th ed., January 1992), profiles institutions with significant holdings of federal, state, local, international, and foreign government documents and lists more than 4,000 professionals in the field. Institutions are arranged alphabetically by city within each state, with summaries of key facts about collection holdings and specialties, staff, and access policies. Indexes are provided by name, subject specialty, collection type, and institution. Copies may be obtained for $\$ 49.50$ (prior to July 31 , 1992) from CIS Customer Service, 4520 EastWest Highway, Bethesda, MD 20814-3389. ISBN 0-88692-224-0.
The Great Spanish Films, 1950-1990, by Ronald Schwartz (134 pages, February 1992), analyzes 70 representative films from Spain produced in the period when Spanish filmmaking began to flourish. Each film is documented with cast, credits, synopsis, production notes, the author's critical commentary, an account of the film's critical reception, and a chronology. A good reminder of a neglected national theme. Copies are available for $\$ 32.50$ from Scarecrow Press, P.O. Box 4167, Metuchen, NJ 08840. ISBN 08108-2488-4.

A Handbook for Scholars, by Mary-Claire van Leunen (348 pages, 2 d ed., February 1992), is an entertainingly written discourse on the technical problems encountered in scholarly writing. Nearly everyone can benefit from browsing through van Leunen's chapters on the use of quotations and such "scholarly peculiarities" as abstracts, capitalization, emphasis, hyperqualification, passivity, personal fads, and "which"-hunting. Although her style for footnotes and references differs from more commonly used manuals, her recommendations for dealing with nonstandard sources are heartening. Available in hardback for $\$ 29.95$ from Oxford University Press, 200 Madison Ave., New York, NY 10016. ISBN 0-19-506953-6.

\section{Librarianship and Information Work} Worldwide 1991: An Annual Survey, edited by Maurice Line, Graham Mackenzie, and Ray Prytherch (240 pages, February 1992), systematically covers the latest international developments in library and information science. Chapters cover the following areas: academic libraries, information for business and industry, public libraries, national libraries, collections, access to information, services, cooperation, management, and education. Most contributors are British, with the exception of three Australasians and one German. A copy may be ordered for $\$ 95.00$ from K.G. Saur, P.O Box 31, New Providence, NJ 07974-9903. ISBN 0-86291-626-7. 
Library Use: A Handbook for Psychology, by Jeffrey G. Reed and Pam M. Baxter (177 pages, 2d. ed., January 1992), is designed for psychology students writing term papers, but anyone else who needs to discover the joys of Psychological Abstracts will also find this book extremely helpful. New to this edition are descriptions of PsycBOOKS, Test Critiques, CDROM sources, and recent handbooks and encyclopedias. Each chapter features a specific topic (eyewitness testimony, aging, stress) that provides a practical demonstration of research techniques and resources. The handbook costs $\$ 19.95$ and is available from the American Psychological Association Order Department, P.O. Box 2710, Hyattsville, MD 20784-0710. ISBN 155798-144-2.

Lucius D. Clay: An American Life, by Jean Edward Smith (835 pages, February 1992), follows the career of the man who served as military governor of a devastated Germany from 1945 to 1949 . Clay's efforts ultimately resulted in a reconstructed and democratic Federal Republic. Clay's experience with the German Autobahn system was the reason that President Eisenhower asked him to head an advisory committee that later resulted in the U.S. interstate highway system. When the border between East and West Berlin was closed in August 1961, President Kennedy asked him to go to Berlin with Vice President Johnson to restore the morale of the West Berliners. Smith devoted nearly 20 years of his life to this definitive biography, which is based on many personal interviews with General Clay. A copy may be purchased for $\$ 19.95$ from Owl Books, Henry Holt and Company, 115 W. 18th St., New York, NY 10011. ISBN 0-8050-1787-9.

\section{Opportunities for Reference Services:} The Bright Side of Reference Services in the 1990s, edited by Bill Katz (213 pages, December 1991), highlights the essential services performed by reference librarians in a series of essays. A potpourri of reference topics for casual reading. Copies are available for $\$ 29.95$ from Haworth Press, 10 Alice St., Binghamton, NY 13904-1580. ISBN 1-56024-137-3.

\section{Optical Character Recognition: A} Librarian's Guide, by Harold C. Ogg and Marlene C. Ogg (171 pages, January 1992), summarizes the capabilities of OCR hardware and software packages as of mid-1991. Written for the library or school environment, the style is minimally technical. An introductory chapter explains the rudiments of character recognition, and even the hardware chapter begins with a basic question: PC or Mac? Other chapters feature graphics, font manipulation, and case studies. Copies are available for $\$ 39.50$ from Meckler Corporation, 11 Ferry Lane West, Westport, CT 06880. ISBN 0-88736-778-X.

\section{Remarkable Journey: The Wright Field Heritage in Photographs (253 pages, Decem-} ber 1991) is a photographic record of the development and maturity of aviation at one of the pioneer military air fields of the United States. This photo-essay traces the evolution of aviation technology at Wright Field, now part of Wright-Patterson Air Force Base. Famous aircraft featured in the photographs include the Curtiss JN-4 primary trainer for U.S. pilots during World War I, the GA-1 twin-engine attack triplane, the XB-35 flying wing, the C- 47 , the YR- $4 \mathrm{~B}$ first production helicopter, and the $\mathrm{B}$ $17, \mathrm{~B}-24$, and B-29 bombers. To order by mail, send a prepayment of $\$ 20.00$ to the Superintendent of Documents, P.O. Box 371954, Pittsburgh, PA 15250-7954. Stock number 008-07000659-6.

\section{Unprofessional Behavior: Contessions of} a Public Librarian, by Will Manley (199 pages, March 1992), will appeal to all types of librarians. If you have an MLS, Manley's humor will touch you as much as Will Rogers touched the funny-bone of Americans in the 1920s and 1930s. You know something is up when you examine the typically boring library-style book cover: the word "Unprofessional" does not fit within the borders allowed for it, so it droops like a wax banana; and, though published by McFarland, the imprints of Scarecrow and Oryx are visible with an overstrike. This book is about breaking the rules and living to talk about it. In the essay "A Patron's Guide to the Library," you will discover that the five main ingredients to create a good library are: "(1) nooks and crannies, (2) a tranquil ambience, (3) Frost/ Hemingway/Steinbeck, (4) sticky, chewy chocolate swirl ice cream with nuts, and (5) passionate librarians." This is information that you will never discover in library school. Do your self-esteem a favor and order this book. It costs $\$ 21.95$ and is available from McFarland and Co., Box 611, Jefferson, NC 28640. ISBN 089950-690-9. 